\title{
Rectal Lipoma
}

National Cancer Institute

\section{Source}

National Cancer Institute. Rectal Lipoma. NCI Thesaurus. Code C5551.

A benign adipose tissue neoplasm of the rectum. 